\title{
HOME EDUCATION IN THE EUROPEAN UNION AND THE NEED FOR UNIFIED EUROPEAN POLICY
}

\author{
Colin Koons*
}

\section{INTRODUCTION}

"[T]he direction in which education starts a man . . will determine his future life." - Plato

The future of a nation is inherently related to the quality of its educational system because education directs not only the lives of individuals but also the future life of the state itself. As a result, education is a crucial area of public policy, and a state has a particular interest and responsibility in guaranteeing that its children are provided with an education and that the education achieves a consistent standard of excellence.

Within the European Union, each Member State retains some level of sovereignty over its own public policies. However, "the [M]ember [S]tates delegate some of their decision-making powers to shared institutions they have created, so that decisions on specific matters of joint interest can be made democratically at European level." 2 For example, the Members have delegated the power to facilitate commerce, establish defense policies, and encourage travel across national borders in the European Union. These delegated powers given to the European Union primarily deal with international issues and the promotion and protection of the European Union. ${ }^{3}$

Although the Member States technically reserve the power over their individual education policies, the European Union remains interested about the quality education in each Member State because education serves as an important function in economic growth. ${ }^{4}$ Thus, the European Union plays a

* J.D. Candidate, Indiana University School of Law-Indianapolis, expected May 2010; B.A. Indiana University-Purdue University Indianapolis, 2007. I would like to thank my parents, Dale and Laura Koons, for their continuing love and support throughout my academic career. Without their determination, strength, and perseverance in my education at home during my primary and secondary school years, this Note would never have been possible.

1. Plato, The RePublic, Book IV, (Benjamin Jowett trans., Random House 1958), available at $\mathrm{http}: / /$ classics.mit.edu/Plato/republic.5.iv.html.

2. European Union Website, EU institutions and other bodies, http://europa.eu/ institutions/index_en.htm. (last visited Nov. 30, 2009).

3. See id.

4. European Union, School Education: Equipping a New Generation, http://ec.europa.eu/ 
significant role in developing policies and initiatives to assist its Member States in developing of their educational systems. ${ }^{5}$

The European Union has noted that although the Members are responsible for the organization and content of their school structures, the challenges facing its Member States are strikingly similar. For example, only seventy-eight percent of twenty-two year-old Europeans complete their secondary education. ${ }^{6}$ Because of these similar obstacles, the European Union encourages a unified European education policy to respond to the challenges Europe faces in "globalization, integration, enlargement, and the economic polarization that is evident among the European regions."7

In an attempt to influence its members' decisions and develop a unified education policy, the European Union sought the public's "views on some important aspects of school education and on future challenges and possible solutions." The survey included responses from the general public, public policy organizations, and academia from across Europe. ${ }^{9}$ The results, published in June 2008, distinguished different methods and concerns that these groups believed were most important in developing a successful education system. The results revealed a strong consensus from respondents "that school curricula and teaching methodologies need to enable students to develop their own learning competences in a more flexible learning environment."10

In fact, a call for a unified educational policy has been made in think tanks across the European Union." The Socires Organization, a civil society

education/lifelong-learning-policy/doc64_en.htm (last visited Sept. 17, 2009) [hereinafter School Education: Equipping a New Generation]. The European Union assists its member states by supporting their national efforts to develop educational systems which "set people on the path to a lifetime of learning, if they are to prepare them adequately for the modern world." $I d$. The European Union's role is primarily twofold. First, the EU injects "millions of Euros each year in projects that promote school exchanges, school development, the education of school staff, school assistantships and more." Second, the EU "works closely with policymakers from Member States to help them develop their school education policies and systems. It does this by gathering and sharing information and analysis and by encouraging the exchange of good policy practice." Id.

5. European Union Website, Public Consultation "Schools for the 21 st century," http://ec.europa.eu/education/school21/index_en.html (last visited Sept. 17, 2009) [hereinafter Public Consultation].

6. School Education: Equipping a New Generation, supra note 4.

7. Richard Edwards and Nicholas Boreham, 'The Centre Cannot Hold': Complexity and Difference in European Union Policy Towards a Learning Society, 18 J. OF EDUC. POL'Y 407, 407 (2003).

8. Commission of the European Communities, Commission Staff Working Document accompanying the Communication from the Commission to the Europeans Parliament, the Council, the European Economic and Social Committee and the Committee of the Regions, 2, COM (2008) 43, available at http://ec.europa.eu/education/school21/sec2177_en.pdf.

9. Public Consultation, supra note 5; See also European Union, Centre for Strategy and Evaluation Service, School's for the $21^{\text {st }}$ Century-Analysis of Public Consultation (June 2008), http://ec.europa.eu/education/school21/results/report_en.pdf [hereinafter ANALYSIS OF PUBLIC CONSULTATION].

10. Analysis of Public Consultation, supra note 9 at pg. ii.

11. Homeschooling vs. the European Union (Nov. 28, 2007, 20:20 EST), 
think tank located in the Netherlands, argues that "a common and coherent position and strategy" is absolutely necessary to produce European freedom of education. $^{12}$ For example, a unified policy promotes inter-European worker mobility because educational quality would remain unchanged with a move across Europe, and parents would have the same educational choices and schooling methods in each Member State. ${ }^{13}$ Other educational policy organizations, such as the European Council of National Associations of Independent Schools, note that the development of any European Union educational policy should encourage flexibility in the educational structures. ${ }^{14}$ In a survey conducted across the European Union, the Council stated that "many schools and national level [organizations] stressed the need for teachers to be able to work autonomously in order to develop the pedagogic strategies that work best for them." 15 These statements from education policy organizations are nearly identical to the public response assembled by the European Union, and they demand flexibility and unique strategic solutions to solve European educational problems. ${ }^{16}$

Home education is an example of a unique pedagogical strategy that provides the flexibility of student autonomy while maintaining high educational levels. In home education, the parent is the primary educator of the child and the majority of the work is done outside of a formal or traditional school setting. ${ }^{17}$ The education that is "provided at home does not necessarily mirror the education provided in government funded schools," because it can include online classes, activities with cooperative homeschool organizations, or individualized reading and discussions. ${ }^{18}$

Home education has received a great deal of attention in the United States, and although specific regulations may vary, home education is generally legal throughout the United States. ${ }^{19}$ As a result, the number of children educated at home in the United States has dramatically increased in the last twenty years. $^{20}$ According to a report by the U.S. Department of Education's National Center for Education Statistics in 2007, the number of children

http://informaledcommunity.atom5.com/homeschooling-vs-eur-1161.html.

12. Socires Organization, Striving for Freedom of Education: A Mapping of European Policy, Jan. 2007, pg. 15, http://www.socires.n1/21/2005A Education Policy Europe.pdf.

13. Home School Legal Defense Association, European Commission to Open Dialogue with Germany on Homeschooling Law, July 29, 2008, http://www.hslda.org/hs/international/ Germany/200807291.asp.

14. EUROPEAN COUNCIL OF NATIONAL ASSOCIATIONS OF INDEPENDENT SCHOOLS WEBSITE, SCHOOLS FOR THE $21^{\text {ST }}$ CENTURY - ANALYSIS OF PUBliC CONSUltation, http://www.ecnais.org/documents/ SummaryofreportSchoolsforthe21 stCentury.040908.doc (last visited Oct. 8, 2009).

15. Id.

16. Id.

17. Amanda Petrie, Home Education in Europe and the Implementation of Changes to the Law, 47 INT'L REV. EDUC. 477, 479 (2001).

18. Id.

19. Id. at 480 .

20. Eric J. Isenberg, What Have We Learned About Homeschooling?, 82 PEABODY J. OF EDUC. 387, 389 (2007). 
educated at home in the United States has grown to over 1.5 million students, nearly three percent of all U.S. school-aged children. ${ }^{21}$ The report also noted an extraordinary surge in the number of children who are educated at home in the last ten years; in 1999, only 850,000 children were educated at home, which was approximately 1.7 percent of all U.S. school-aged children. ${ }^{22}$

Parents who choose to educate their children at home do so for a variety of reasons. Some scholars note that formal schools "have lost some of their legitimacy as they have lost a clear functional role in preparing youth for their role in the larger economic system," 23 and by educating their children at home, parents attempt to regain power over their children's education and remove them from traditional schools. In the United States, the National Center for Education Statistics noted in its 2007 report that "parents homeschooled their children for a variety of reasons, but three reasons-to provide religious or moral instruction, concern about the school environment, and dissatisfaction with the academic instruction at other schools" remain the prominent motivations. $^{24}$

In contrast to the United States, the laws concerning home education widely vary across the European Union. At one extreme, several Member States completely restrict any type of home education; at the other extreme, some Member States recognize home education as a valid educational choice and leave the decision to the parents. ${ }^{25}$ Likewise, public interest in home education is also varied, but the strongest interest is mostly centered in the United Kingdom and France, both of which allow parents to choose between various educational methods. ${ }^{26}$

As the European Union's power has developed amid sovereign European community members, there have been occasional situations in which the powers delegated to the European Union have directly conflicted with the reserved powers of the Member States. For example, several instances were documented in which migrant workers have been forced to leave one Member

21. Nat'l Center for Educ. Statistics, U.S. Dept. of Educ., 1.5 Million HoMESCHOOLED STUDENTS IN THE UNITED STATES IN 2007 (Dec. 2008), http://eric.ed.gov/ERICDocs/ data/ericdocs2sq1/content_storage_01/0000019b/80/42/b1/4b.pdf.

22. Id.; see also D.V., Home Schooling, EDUC. WeEK, Feb. 21, 2009.

23. Kurt J. Bauman, Home Schooling in the United States: Trends and Characteristics, 10 EDUC. POL'Y ANALYSIS 26 (2002), available at http://epaa.asu.edu/epaa/v10n26.html.

24. National Center for Education Statistics, U.S. Dept. of Education, supra note 21.

25. See generally HSLDA: Home Schooling - International page, http://www.hslda.org/hs/ international/default.asp (last visited Oct. 11, 2009). The Home School Legal Defense Association (HSLDA) is a non-profit organization located in the United States which was "established to defend and advance the constitutional right of parents to direct the education of their children and to protect family freedoms." HSLDA: About HSLDA, http://www.hslda.org/ about/default.asp (last visited Oct. 11, 2009). HSLDA provides legal services, research, and lobbying efforts for home education in the United States and around the world. Id.

26. See generally Lesley A. Taylor \& Amanda J. Petrie, Home Education Regulations in Europe and Recent U.K. Research, 75 PEABODY J. OF EDUC. 49 (2000); see also HSLDA: Home Schooling - International, http://www.hslda.org/hs/international/default.asp (last visited Oct. 11, 2009). 
State and migrate to another in order to avoid compulsory state education. ${ }^{27}$ In this situation, a unified European education policy would assist the European Union's goal of a unified economic policy.

This Note will focus on the legality of home education in the European Union's Member States and its future within the European Union's political and economic policies. In Part II, the differences of the home education laws in Europe will be examined, using Germany and the United Kingdom to compare and contrast the extreme positions in Europe. Part III will analyze the differences between the Member States by examining them in light of the major European agreements which form the European Union and the European Court of Human Rights. Specifically, this is developed by examining the European agreements that promote the state's protection of a child's right to education while preserving the right of parents to direct the type and quality of their children's education. These agreements have direct consequence on any possible unified stance in the European Union concerning education specifically and on the future of human rights in the European Community generally. Finally, Part IV will focus on how home education fits within the stated policy positions and goals of the European Union and whether home education should play a role in the future policy decisions of a unified Europe.

\section{THE LEGALITY OF HOME EDUCATION IN EUROPE}

The laws concerning home education vary greatly among the Europe Union Member States. Some Members allow or encourage home education, while other countries completely ban its use. Amanda Petrie, a research fellow of education at the University of Liverpool, has grouped the Member States into three categories. ${ }^{28}$ Although it is only a rough summarization, Petrie's categorization provides a framework in which to analyze the legality of home education in Europe.

Petrie's first category consists of "those countries which accommodate home educators and have always done so." 29 Although the countries in this group may have some light regulations concerning its use, home education is generally legal. For example, England, Ireland, and France have legalized homeschooling, and although there may be some minor restrictions, these three countries give a great deal of flexibility in allowing parents to shape their children's education. ${ }^{30}$

27. Home School Legal Defense Association, European Commission to Open Dialogue with Germany on Homeschooling Law, July 29, 2008, http://www.hslda.org/hs/intemational/ Germany/200807291.asp.

28. Petrie, supra note 17 , at 483.

29. Id.

30. See generally HSLDA: Home Schooling - International, supra note 25. The HSLDA International webpage provides a general outline of the legality of home education around the world, and the webpage provides information for most of the European Union member countries. 
Petrie's second category includes those countries which, although historically preventing or outlawing home education, have changed or updated their systems to permit home education. ${ }^{31}$ However, the countries in this category often highly regulate and restrict home education's use. ${ }^{32}$ For example, Hungarian home educators must follow a mandatory state curriculum and be tested twice a year. ${ }^{33}$

Finally, Petrie's third category identifies those countries which "no longer permit home education in the word of the law, but would appear to permit individual instances."34 Essentially, although not technically illegal, the national regulations in these countries are so strict that home education is effectively banned. $^{35}$ For example, although Germany does not actually prohibit home education, it requires compulsory state education at a state school until age 16 , which effectively makes home education illegal. ${ }^{36}$ However, local German authorities are given some discretion to allow home-education with professional tutors, but this usually only occurs in extraordinary circumstances, such as celebrity children or children with such severe disabilities that they are completely unable to attend school. ${ }^{37}$

Because Petrie's categories represent such a wide range of laws, it is helpful to closely examine the ends of the spectrum to provide clarification. Lying at the most restrictive end of the spectrum, Germany represents the notable example of a country in Petrie's third group because it has been the harshest on home education and has consistently limited its use. ${ }^{38}$ At the other end, the United Kingdom has officially recognized home education as an alternative to state or private schools, and it is considered to have some of the most liberal education laws among the European Union's Member States. ${ }^{39}$

\section{A. Home Education and Germany}

German national law does not technically prohibit home education

31. Petrie, supra note 17 , at 483 .

32. Id.

33. Home Education in Germany: Homeschooling - International, $\mathrm{http} / / \mathrm{www}$.hausunterricht.org/html/hs international.html (last visited Oct. 11, 2009). The original webpage is in German, but an informal translation has been performed through http://translate.google.com.

34. Petrie, supra note 17 , at 483.

35. Id. at 484 .

36. Home Education in Germany, The Legal Situation in Germany, http://www.hausunterricht.org/html/rechtliches.html (last visited Oct. 11, 2009). The original webpage is in German, but an informal translation has been performed through http://translate.google.com.

37. Scatty, Why home education is verboten in Germany, http://gfoh.blogspot.com/ 2007/05/why-home-education-is-verboten-in.html, (May 17, 2007, 8:49 EST).

38. Thomas Spiegler, Home Education in Germany: An Overview of the Contemporary Situation, 17 EVALUATION \& RES. EdUC. 167, 179-80 (2003).

39. See HSLDA: Home Schooling - United Kingdom, http://www.hslda.org/hs/ international/UnitedKingdom/default.asp (last visited Oct. 11, 2009). 
because the local officials have the ability to enforce national school requirements as they see fit. ${ }^{40}$ However, the local authorities have used this authority to actively prevent home education except in rare circumstances such as children involved in musical careers. ${ }^{41}$ Some researchers estimate that only 500 children in Germany are educated at home, whether "in secret, with tacit toleration by the local authorities[,] or with legal consequences [which] rang[e] from a fine to partial loss of child custody, or even the possibility of a prison sentence., ${ }^{, 42}$

Although the reasons for refusing to legalize home education vary, a major reason for this hostility stems from the German government's view that home education harms both the children and society. ${ }^{43}$ For example, one German court stated that children should be removed from their parents for home educating "in order to protect the children from further harm. ${ }^{, 44}$ Indeed, a local education official brought a case against two families who were educating their children at home because he claimed it was "a right of the child not to be kept away from the outside world," and that "[ $[$ ]he parents' right to personally educate their children would prevent the children from growing up to be responsible individuals within society." the local education official and appointed a public guardian over the children, stating that the parent's actions were "a stubborn contempt both for the state's educational duty as well as the right of their children to develop their personalities by attending school., ${ }^{, 46}$

This type of governmental treatment of German home educators is not unusual. For examine, a young girl was forcibly taken from her family and placed into a psychiatric ward because her parents had educated her at home. ${ }^{47}$ She originally attended a state school, but when local school officials claimed that she had been falling behind in her grades, her parents began giving her tutoring at home after her school classes. The local officials, who strongly disagreed with any kind of home education, expelled her from the state school for receiving any home tutoring. ${ }^{48}$ Because she had been expelled, her family

40. Spiegler, supra note 38 , at 181.

41. Id.

42. Mary Ann Zehr, U.S. Home Schoolers Push Movement Around the World, Educ. WEEK, Jan. 4, 2006, at 8.

43. Spiegler, supra note 38 , at 188.

44. Alexandra Cohen, Hitler's Ghost Haunts German Parents, Brussels Journal, Aug. 8, 2005, http://www.brusselsjournal.com/node/139.

45. Id.; See also Home School Legal Defense Association, "Homeschooling Illegal" Declares German School Official, Jan. 7, 2005, http://www.hslda.org/hs/international/Germany/ 200501100.asp.

46. Cohen, supra note 44 .

47. Charlie Francis-Pape \& Allan Hall, Home-school Germans flee to UK, THE OBSERVER, Feb. 24, 2008, available at http://www.guardian.co.uk/education/2008/feb/24/schools.uk.

48. Bob Unruh, Girl sent to Psych Ward for Homeschooling, Parents Billed, WORLDNETDAIY, Mar. 30, 2008, http://worldnetdaily.com/index.php?fa=PAGE.view\&pageld $=59947$. 
was forced to home educate her full time; however, the officials continued to object, and they quickly removed her from her home and placed her into state custody. ${ }^{49}$

In another case, an American family living in Germany was fined approximately $\$ 2,300$ per child for home educating their children. ${ }^{50}$ In July 2008 , another family was fined approximately $\$ 1,200$ for home educating in Germany, and the parents were given a ninety day prison sentence. ${ }^{51}$

However, such harsh resistance to home education has not been limited to the local level but has included opposition at the national level. Officials at the German embassy in Washington, D.C., have defended Germany's position on home education, stating that " $[t]$ he public has a legitimate interest in countering the rise of parallel societies that are based on religion or motivated by different worldviews." 52 Indeed, some German national officials have commented that home education in Germany is essentially impossible and that any discussion of nationwide legality for home education would be rejected from any governmental agenda. ${ }^{53}$

German families who continue to educate their children at home, despite the ban on home education, state a variety of reasons for their choice. For example, one family claimed that after a two-year posting away from Germany, they were discouraged by the lack of variety that they found in German schools, especially in languages and science, and they turned to home education when their children were unable to adapt to the German school system. ${ }^{54}$

Although a few local officials turn a blind eye to an occasional instance of home education, many parents are forced to flee Germany in order to find a country with more friendly education laws, and they often look to the United Kingdom or the United States. ${ }^{55}$ For example, one German family is seeking refuge in Tennessee after local German officials forcibly took the children to a state school, and the family felt "they had no choice but to move abroad after authorities came to their home to enforce the [compulsory state education] law."

49. Id.

50. Taylor \& Petrie, supra note 26 , at 52.

51. Home School Legal Defense Association, Appeals Court Orders New Trial for Homeschoolers Sentenced to Prison, Jan. 9, 2009, http://www.hslda.org/hs/international/ Germany/200901090.asp. The parent's prison sentence was later overturned on other grounds. Id.

52. Zehr, supra note 42.

53. Home School Legal Defense Association, Highs and Lows of Two Families Illustrate Challenges for Homeschoolers, Sept. 15, 2008, http://www.hslda.org/hs/international/Germany/ 200809150.asp.

54. Cynthia Guttman, European Disunity, UNESCO COURIER, June 2000, at 15, available at http://www.unesco.org/courier/2000_06/uk/apprend2.htm.

55. Francis-Pape and Hall, supra note 47.

56. Christina Bergmann, German Family Fled to US for Educational Freedom, DeUTSCHE WELLE, Feb. 1, 2009, http://www.dw-world.de/dw/article/0,3979558,00.html. A federal immigration judge was scheduled to announce a ruling on January 26,2010 , concerning whether 
in the United States and "hopes that their application for political asylum will be successful and that they will be granted permanent residence and work permits in the United States." 57 Such attempts to seek political asylum abroad are not uncommon for those who have attempted to home educate in Germany, and approximately seventy-eight home educated children and their families fled Germany in 2007 to avoid persecution from local officials. ${ }^{58}$

\section{B. Home Education and the United Kingdom}

While Germany sits at the furthest end of Petrie's spectrum, essentially restricting home education altogether, the United Kingdom is at the opposite end. The United Kingdom has some of the most liberal education laws in the European Union and directly permits home education by national law. ${ }^{59}$ It is estimated that between 45,250 to 160,000 children are home educated in the United Kingdom, and those numbers are rapidly increasing. ${ }^{60}$ However, it is extremely difficult to calculate the number of home educators because "there is currently no obligation in law for families to register that their children are receiving their education in this manner."61

Under British law, parents have the responsibility to give their school age children "efficient full-time education ... e either by regular attendance at school or otherwise."62 Parents must only assure the local school board that their children are receiving an appropriate education. ${ }^{63}$ Further, the law states that local authorities must follow the general principle that students are to be educated "in accordance with the wishes of their parents," as long as the parental choice would give the child efficient instruction while avoiding "unreasonable public expenditure.",64

Although the procedures for home education vary in different parts of the United Kingdom, "education" is considered to be compulsory rather than "schooling." 65 Although this word choice might seem inconsequential, it has

the family would be granted political asylum in the United States. See Home School Legal Defense Association, Decision in Romeike Political Asylum Case Delayed, January 20, 2010, http://www.hslda.org/hs/international/Germany/201001200.asp. As of this Note's writing, the decision had not yet been released.

57. Id.

58. Francis-Pape \& Hall, supra note 47.

59. Home Education in Germany: Homeschooling - International, supra note 33.

60. Vicky Hopwood et al., The Prevalence of Home Education In ENGland: A FEASIBILITY STUDY, available at http://www.parliament.uk/deposits/depositedpapers/ 2008/DEP2008-1324.pdf.

61. Karen McIntyre-Bhatty, Interventions and Interrogations: An Analysis of Recent Policy Imperatives and Their Rationales in the Case of Home Education, 1 EDUC., KNOWLEDGE, \& ECON. 241, 242 (2007).

62. Education Act, 1996, c. 1, $§ 7$ (Eng.), available at http://www.opsi.gov.uk/Acts/acts 1996/ukpga_19960056_en_2\#pt1-ch1-pb3-l1g7.

63. Home Education in Germany: Homeschooling - International, supra note 33.

64. Education Act, 1996, c. 1, § 9 (Eng.), available at http://www.opsi.gov.uk/Acts/ acts1996/ukpga_19960056_en_2\#pt1-ch1-pb3-11g7.

65. Education Otherwise: The Law, http://www.education-otherwise.org/legal.htm (last 
significant effect in the debate for home education, and this significance is discussed infra at Parts III and IV. In the United Kingdom, parents are allowed to choose home education for a variety of reasons, but the guidelines require that the "local authority's primary interest should lie in the suitability of parents' education provision and not their reason for doing so."

Although the national law specifically permits its use, home education has recently come under attack in the United Kingdom. The Baroness Morgan of Drefelinhas, the United Kingdom's Children Minister, has challenged home education as a harbor for parental "abuse, neglect, forced marriage, sexual exploitation or domestic servitude" and has called for a review of the local rules covering home education. ${ }^{67}$ This review will examine whether the local authorities should have more power to enter a home and inspect the quality of education given to the children. ${ }^{68}$

The announcement of the review has been received with mixed reaction. The home education community in the United Kingdom has decried the review as offensive and believes that "[no] other community would be expected to suffer the prejudice and discrimination which our community has to endure." British home education advocates are concerned about new regulations because they claim that if the local governments are given swingeing powers to restrict home education, their children's education will suffer because nearly sixty percent of British home educated school children have been withdrawn from a formal school because of bullying, assault, or special needs. ${ }^{70}$ British parents also claim that they have chosen to educate their children at home because of the reduction in educational quality at British schools. ${ }^{71}$

Some home education groups have compared the review to any full-scale review that would be made of the location, numbers, and activities of the

visited Oct. 11, 2009). Education Otherwise is a British organization "that provides support and information for families whose children are being educated outside school, and for those who wish to uphold the freedom of families to take proper responsibility for the education of their children." Education Otherwise: About us, http://education-otherwise.org/abouteo.htm (last visited Oct. 11, 2009). This organization provides services similar to those offered by HSLDA, mentioned supra note 25, and supplies access to contacts, resources, and informational exchanges in the United Kingdom. Id.

66. DEPARTMENT FOR CHILDREN, SChOOLS, AND FAMILIES, Elective Home Education: GUIDELINES FOR LOCAL AUTHORITIES, at 3 (2007), available at http://www.dcsf.gov.uk/ everychildmatters/_download/?id=1905.

67. Alexandra Frean, Home education 'Can be Cover for Abuse and Forced Marriage,' ThE TIMEs ONLINE, Jan. 20, 2009, http://www.timesonline.co.uk/tol/life_and_style/education/ article5549380.ece.

68. Id.

69. Graeme Paton, Children's Minister: Home Education 'May be Cover for Abuse, ' THE TELEGRAPH, Jan. 19, 2009, http://www.telegraph.co.uk/education/4291728/Childrens-MinisterHome-education-may-be-cover-for-abuse.html.

70. Adi Bloom, Home Education a Cover for Abuse? Supporters Denounces 'Slur, ' THE Times Educational Supplement, Jan. 30, 2009, Section News, at 25, available at http://www.tes.co.uk/article.aspx?storycode $=6007914$.

71. Graeme Paton, Parents teaching children at home rather than send them to failing schools, THE TELEGRAPH, Jan. 31, 2009, http://www.telegraph.co.uk/education/4398402/ Parents-teaching-children-at-home-rather-than-send-them-to-failing-schools.html. 
Muslim community simply because "some" Muslims have participated in terrorism. ${ }^{72}$ However, other organizations strongly approve a review of home education rules and legislation and assert that "the existing legislation and guidance on elective home education is outdated." 73

Because of the United Kingdom's liberal education laws, most research on home education in the European Union has been done in the United Kingdom. ${ }^{74}$ Paula Rothermel, a British educational psychologist and specialist in home education, notes that religion is not a strong motivation for home education. Relying heavily upon her personal research and experience with home educated families, ${ }^{75}$ Rothermel reports that "only about 4 percent of the 412 British home-schooling families she surveyed said religion was a motive for home schooling. Nearly thirty-one percent cited disappointment with regular schools.",76

This examination of the situations in Germany and United Kingdom reveals the greater issues at stake in the home education debate. These issues include the parents' right to raise their children in a manner they see fit; the state's responsibility to assure an educated public, a responsibility particularly important in a democratic era to ensure that public officials are thoughtfully elected; and the child's independent right to choose their own education.

Beyond the scope of this Note, there is a debate whether the parent or the state is a better guardian or representative of the child's choice. Although this Note discusses the rights of parents, the state, and the child, it does not specifically address whether the state or the parent is the best representative of the child's rights. However, the right of the parent has been a right that has been a respected part of the West's history. ${ }^{77}$ Thus, it is assumed that the parental right should be respected along with the state's responsibility to promote the children's interests.

\section{Home EducATION, EUROPEAN COURTS, AND HuMAN RIGHTS}

Because of the potential conflict between a parent's rights and the state's rights, the national courts across Europe have vainly attempted to find a judicial standard. Essentially, the conflict of rights comes down to constitutional interpretation of human rights, and the European Convention on Human Rights

72. Ann Newstead, The Government is Victimising Parents Who Home Educate, THE TELEGRAPH BLOGS, http://blogs.telegraph.co.uk/ann_newstead/blog/2009/01/22/the_government is_victimising_parents_who_home_educate, (Jan. 22, 2009 10:12 GMT).

73. Mithran Samuel, DCSF Launches Home Education Review and Safeguarding Concerns, CommunityCare.co.uk (Jan. 20, 2009), http://www.communitycare.co.uk/Articles/ 2009/01/20/1 10495/dcsf-launches-home-education-review-amid-safeguarding-concems.html.

74. Guttman, supra note 54.

75. Paula Rothermel Website, Expert Witness Specialising in Home Education, http://www.pjrothermel.com/ExpertWitness/Introduction.htm (last visited Sept. 15, 2009).

76. Zehr, supra note 42.

77. McIntyre-Bhatty, supra note 61, at 241-42 ("[T] hroughout history, children's education has always been the responsibility of their parents."). 
is the controlling human rights document in the European Community. ${ }^{78}$ The Convention, signed at Rome in 1950 , is the treaty by which the forty-seven "[M]ember [S]tates of the Council of Europe undertake to respect fundamental freedoms and rights."

The Convention established the European Court of Human Rights, and a human rights violation by any of the member countries may be appealed to the Court. Since 1998, any individual in a contracting state has the "right of action to assert the rights and freedoms to which they are directly entitled under the Convention." ${ }^{180}$ The Court, however, does have discretionary power over hearings, and it may refuse an appeal if it finds an application to the Court to be manifestly ill-founded. ${ }^{81}$

The European Convention of Human Rights relates directly to the home education debate because it guarantees the right to education. ${ }^{82}$ In Article 2 of the First Protocol to the Convention, the treaty affirms that:

No person shall be denied the right to education. In the exercise of any functions which it assumes in relation to education and to teaching, the State shall respect the right of parents to ensure such education and teaching in conformity with their own religious and philosophical convictions. ${ }^{83}$

Using the Convention's requirement that a state must respect parental rights in education, several German parents, who have attempted to refuse Germany's mandatory state schooling and home educate, have appealed to the Court of Human Rights. ${ }^{84}$

78. Convention for the Protection of Human Rights and Fundamental Freedoms, art. 2, Nov. 4, 1950, http://www.echr.coe.int/NR/rdonlyres/D5CC24A7-DC13-4318-B4575C9014916D7A/0/ EnglishAnglais.pdf [hereinafter European Convention on Human Rights] The Convention was first signed at Rome in 1950, and then later ratified individually by its members, and it is also known as the European Convention on Human Rights. Council of Europe website, Signature Lists, http://www.echr.coe.int/NR/rdonlyres/D5CC24A7-DC134318-B457-5C9014916D7A/0/ EnglishAnglais.pdf (last visited Sept. 15, 2009). The First Protocol to the Convention, dealing with the rights to property, education, and free elections, was signed March 20, 1952. Id.

79. Council of Europe, What's what?, http://www.coe.int/T/E/Com/About_Coe/ whatswhat.asp (last visited Sept. 15, 2009).

80. The European Court of Human Rights, Information document on the Court, para. 4 (2006), http://www.echr.coe.int/NR/rdonlyres/981B9082-45A4-44C6-829A-202A51B94A85/0/ ENG_Infodoc.pdf.

81. The European Court of Human Rights, Some Facts and Figures 1998-2008, at 3 (Nov. 2008), http://www.echr.coe.int/NR/rdonlyres/65172EB7-DE1C-4BB8-93B1-B28676C2C844/0/ FactsAndFiguresENG10ansNov.pdf. In 1998, Protocol 11 was added to the Convention, recognizing the right to Individual Applications to the Court. See Protocol No. 11 to the Convention, art. 34, available at http://conventions.coe.int/Treaty/en/Treaties/Html/155.htm.

82. European Convention on Human Rights, supra note 78, at art 2.

83. Id.

84. Francis-Pape and Hall, supra note 47. 
In 2006, a German parent who tried to educate her child at home appealed to the European Court of Human Rights in Konrad and Others $v$. Germany after German officials refused to allow him to home educate; however, the appeal was denied because the Court held the claim was inadmissible. ${ }^{85}$ The Court stated that the case was rejected because of the concern the Court had for parallel societies that develop through home education. "The acquisition of social competence in dealing with other persons who hold different views and in holding an opinion which differed from the views of the majority could only [materialize] through regular contact with society." ${ }^{87}$ Essentially, the Court approved of the view that only through a traditional school setting can a state ensure the education of a citizenry ready to "participate in a democratic and pluralistic society" because the "[e]veryday experience with other children based on regular school attendance was a more effective means to achieve that aim than home education." 88

However, the Court did not ignore the interest of the parents, but it attempted to balance the interest of the parents against "the general interest of society in the integration of minorities and in avoiding the emergence of parallel societies ....,"89 The Court held that parents could supplement their children's education but that they could not keep their children from compulsory state education. ${ }^{90}$

This decision reveals a conflict in the various interpretations of the Convention's language because the Court did not determine what is required in "the right to education." In Konrad, the Court of Human Rights essentially recognized the right to "schooling," a term which is interpreted much broader than just "education." Education is the actual education of the child, such as learning to read and write. Schooling, on the other hand, is a broader term and requires formal education as well as the social environment of the traditional school and classroom setting. ${ }^{92}$

In Leuffen v. Federal Republic of Germany, a case extraordinarily similar to Konrad, the difference between "schooling" and "education" was similarly distinguished by the European Commission of Human Rights. In that case, the Commission held a home education claim to be inadmissible because the parents were unable to sufficiently meet their educational needs of their

85. Summary of Konrad and Others v. Germany, Eur. Ct. H.R. No. 35504/03 (2006), http://www.echr.coe.int/Eng/InformationNotes/INFONOTENo89.htm [hereinafter Summary of Konrad].

86. European Court of Human Rights, Fifth Section Decision as to the Admissibility of Application no. 35504/03 Fritz KONRAD and Others against Germany (2006), http://cmiskp.echr.coe.int/tkp 197/view.asp?action=html\&documentId=808899\&portal=hbkm\&s ource=externalbydocnumber \&table=F69A27FD8FB86142BF01C1 166DEA398649.

87. Summary of Konrad, supra note 85.

88. Id.

89. Id.

90. Id.

91. Id.

92. Petrie supra note 17 , at 479. 
children." Although Leuffen was "a significant challenge to the claims of home educators," Daniel Monk, a senior lecturer at Birkbeck College School of Law, University of London, notes that "it is important to acknowledge its weaknesses." 94 He comments that the interpretation is unclear because the Commission placed emphasis "on both the inability of Leuffen to educate her child and the importance of the child's right to education, giv[ing] credence to the possibility that the Commission simply 'confused' schooling with education." 95

However, Amanda Petrie, a research fellow at the University of Liverpool, argues that the parent's ability in Leuffen was never actually reviewed by the Commission or by the local education authorities. ${ }^{96}$ The mother in Leuffen "had religious reasons for home educating her son; she also felt that she could give her son a wider education than that provided at school[, however $h$ ]er ability to home educate was never assessed, the school authorities stating that home education was not permitted." 97 When the Commission held the mother's claim inadmissible, the mother was forced to flee to London, where she continued to successfully home educate her son. ${ }^{98}$ After she moved to England, the local British school authorities noted that the son "maintained his enthusiasm and eagerness to learn and constantly find out more about his environment. He seem[ed] to be a very happy child and relate[d] very well to other people." 99

Like the Commission's decision in Leuffen, the Konrad Court did not explicitly state that the right to education means "schooling." In addition, because this is not an official decision, but merely reason for rejecting an appeal, the Court is not bound to the language of Konrad. However, if the Court follows its potential policy in Konrad and requires "schooling" as a part of "education," this would mean that a parent could never give the child an education in the home and the child must be educated in a traditional school. As Daniel Monk explicitly states, if the "right to education" in Article 2 of the First Protocol to the Convention is interpreted as only given through attendance

93. European Commission of Human Rights, Leuffen v. F.R.G. (1992) App. No. 198441/92, Eur. H.R. Rep. Until 1998, an individual could only bring a Human Rights case before the Commission. See The European Court of Human Rights, Some Facts and Figures 1998-2008, supra note 81. When Protocol 11 was passed in 1998, it changed the structure of the appeals process for a violation of the European Convention on Human Rights cases, and an individual citizen could bring a human rights case in the European Court of Human Rights. Id. Thus, this case was brought in the European Commission of Human Rights, whereas Konrad was brought in the European Court of Human Rights in 2006.

94. Daniel Monk, Problematizing home education: challenging 'parental rights' and 'socialisation,' 24 LEGAL STUDIES 568, 582 (2004).

95. Id. at 586.

96. Amanda Petrie, Home Educators and the Law within Europe, 41 INT'L REVIEw of EDUC. 285, 293 (1995).

97. Id.

98. Id.

99. Id. 
at a state school institution, "then it can be argued that no parent is capable of ensuring the education of his or her child at home and that in effect school attendance is essential for "education.' "100 Monk acknowledges that this argument relies on the assumptions "that social and developmental benefits form part of the right to education" and "that only school attendance can provide this form of education."101

Although Monk directs his argument against home education because of the socialization concerns, he admits that "what is more surprising is that despite the prevailing common-sense perception that attending school per se is a 'good thing' and necessary for healthy child development there is remarkably little evidence and no specific research which explicitly supports this claim."

Similarly, Chris Lubienski, an assistant professor in the Department of Curriculum and Instruction at Iowa State University, admits in his critique of home education that most arguments that home education "inhibits the proper socializations" are claims that are "overblown." ${ }^{103}$ He points out that "[t]here is little reason to think that [home education] - if done correctly - cannot introduce a child to basic social norms, at least as transmitted through a given family."104 However, Lubienski argues that home education will not provide an equally diversified social experience as state schools. ${ }^{105}$

If the European Court of Human Rights eventually interprets "the right to education" to be the "right to schooling," a direct conflict could result between the Convention and the reserved policies of the European Union's Member States. For example, the United Kingdom has not recognized the right to schooling, and it has specifically allowed home education to be a valid alternative that fulfills "the right to education." 106 Thus, the United Kingdom's policy of allowing home education could be directly threatened if a case is ever brought to the Court of Human Rights and the Court specifically requires a right to schooling. ${ }^{107}$

However, according to Monk, the threat of a conflict may not exist because the "[a]uthority for a broad definition of education can be found in a

100. Monk, supra note 94 , at 586.

101. Id.

102. Id. at 591 .

103. Chris Lubienski, $A$ Critical View of Home Education, 17 Evaluation and RES. IN EDuc. 167, 170-71 (2003).

104. Id. at $170-71$.

105. Id. at 171.

106. See DePARTMENT FOR CHIIDREN, SchOOLS, AND FAMILIES, Elective Home EduCATION: GUIDELINES FOR LOCAL AUTHORITIES, supra note 66. The regulations which guide local authorities directly state that home education is a valid and optional means of education. Even the guidelines themselves refer to allowing the parents choose their children's education, whether in the state school, private schools, or by some means of education "otherwise." See Education Act, supra note 62.

107. See A-Level-Law.com, Judicial Precedent, http://www.a-level-law.com/els/judicial precedent.htm (last visited Sept. 15, 2009) ("Under the Human Rights Act 1998, English courts must now have regard to decisions of the European Court of Human Rights."). 
number of sources. Most importantly, the second sentence of art 2 of the First Protocol refers to both 'education' and 'teaching' ...."108 Thus, Monk notes that the European Court of Human Rights gives the "two words . . . distinct meanings." He points out that the Court "argued that 'education' included the development and moulding of the character and mental powers of its pupils' and referred to, "the whole process whereby, in any society, adults endeavour to transmit their beliefs, culture and other values to the young ...."109 On the other hand, "'teaching' or 'instruction' refers in particular to the transmission of knowledge and to intellectual development."

Monk also finds support for his interpretation of education in the United Nations Convention on the Rights of the Child of 1989. ${ }^{111}$ Article 29 of that Convention declares that, "[T]he education of the child shall be directed to ... the development of the child's personality, talents and mental and physical abilities to their fullest potential."112 However, the Convention on Rights of the Child is balanced against the rights given in the United Nations Universal Declaration of Human Rights because the Convention on the Rights of the Child specifically recognizes that "everyone is entitled to all the rights and freedoms set forth" in the Declaration. ${ }^{113}$

Although the United Nations Universal Declaration of Human Rights is not binding on the European Court of Human Rights, it is of value to compare the Declaration with the European Convention on Human Rights because the Convention was based upon and closely follows the language of the United Nations Declaration. ${ }^{114}$ In Article 26, the Universal Declaration states that:

Everyone has the right to education. Education shall be free, at least in the elementary and fundamental stages. Elementary education shall be compulsory ... Education shall be directed to the full development of the human personality and to the strengthening of respect for human rights and fundamental freedoms ... . Parents have a prior right to choose the kind of education that shall be given to their children. ${ }^{115}$

The Special Rapporteur on Education to the United Nations Human Rights Council, a position created to monitor the enforcement of the right to

108. Monk, supra note 94 , at 586 .

109. Id. (citing Campbell v. U.K., 4 Eur. Ct. H.R. 293 (1982)).

110. Id.

111. Id.

112. Convention on the Rights of the Child, G.A. Res. 44/25, art. 29(1)(9), U.N. Doc. A/RES/44/2 (Sept. 2, 1990), available at http://www2.ohchr.org/english/law/crc.htm [hereinafter Convention on the Rights of the Child].

113. Id. at preamble, para. 4.

114. The Open University, Part B: The European Convention on Human Rights, http://openlearn.open.ac.uk/mod/resource/view.php?id=282268 (last visited Mar. 9, 2009).

115. Universal Declaration of Human Rights, G.A. Res. 215(111), (Dec. 10, 1948), available at http://www.un.org/en/documents/odhr. 
education in the Universal Declaration, has stated that home education should be a valid educational option. ${ }^{116}$ In his report on the right to education in Germany, the Special Rapporteur claimed that "education may not be reduced to mere school attendance and that educational processes should be strengthened to ensure that they always and primarily serve the best interests of the child." 117 In fact, he directly supported alternatives to formal school education and stated that "[d]istance learning methods and home schooling represent valid options which could be developed in certain circumstances, bearing in mind that parents have the right to choose the appropriate type of education for their children, as stipulated in article 13 of the International Covenant on Economic, Social and Cultural Rights." 118

Larry Willmore, a research scholar at the International Institute for Applied Systems Analysis and a former economic affairs officer for the United Nations, comments that parental choice is often ignored in the debates about freedom in education. ${ }^{119}$ Under the Universal Declaration of Human Rights, the right to education is more frequently discussed in the international arena than the right of parents to choose the type of education for their children, "even though this human right, without question, is violated more frequently than the right to free education." 20 willmore argues that "[t ${ }^{\text {his }}$ neglect is unfortunate, since school choice is known to improve the quality of education in general and in state schools in particular by making them more accountable to parents and students ....".121

Although the European Union is a completely separate agreement from the European Convention on Human Rights, it plays a significant role in the development of European Union policy because the "[M] ember [S]tates of the EU agreed that no state would be admitted to membership of the EU unless it accepted the fundamental principles of the European Convention on Human Rights and agreed to declare itself bound by it." ${ }^{.122}$

\section{HOME EDUCATION AND FUTURE EUROPEAN UNION POLICY}

In 1993, the European Union established a single European market with the purpose to unify and strengthen Europe, economically and politically, by developing trade and eliminating economic barriers within Europe. ${ }^{123}$ Because

116. United Nations Human Rights Council, Report of the Special Rapporteur on the right to education, Mission to Germany, A/HRC/4/29/Add.3 (Mar. 9, 2007) at 15, para. 62, available at http://www.hslda.org/hs/international/Germany/Munoz_Mission_on_Germany.pdf [hereinafter Report of the Special Rapporteur].

117. Id.

118. Id.

119. Larry Willmore, Basic Education as a Human Right: 'Education for All' through . Privatisation? 24 ECON. AfF. 20-21 (2004).

120. Id.

121. Id.

122. The Open University, supra note 114.

123. EUROPA, The EU at a glance, Europe in 12 lessons - the Single Market, para. I(b), 
education is crucial to future economic development, the European Union recognizes that knowledge, education, and training "are the EU's most valuable assets, particularly as global competition becomes more intense in all sectors." policy that "supports, develops and implements lifelong learning policies with the aim of enabling countries to work together and to learn from each other, with an important emphasis on mobility." 125

The European Union itself was established by a series of treaties that work in tandem to create a unified Europe, and these treaties are controlling upon any Member State which has agreed to the Union. ${ }^{126}$ The first of these agreements, the Treaty Establishing the European Community, includes general provisions concerning the creation of the European Union, and this treaty, as amended in the Treaty of Amsterdam, covers general policy issues. ${ }^{127}$ The second treaty, the Treaty on European Union, signed in Maastricht, focuses more on the economic policies of the Union. ${ }^{128}$

In 2001, the Treaty Establishing the European Community and Treaty on European Union were merged together by the Treaty of Nice, and these governing documents provide the general policy goals and purposes of the European Union. ${ }^{129}$ The following section examines these stated policy goals and the role that home education may play in developing and achieving their objectives.

\section{A. General Policy Objectives of the European Union Governing Treaties}

Through the Treaty of Nice, the Treaty Establishing European Community and the Treaty on European Union were merged into a consolidated document, along with any amendment which had been previously made to these treaties. However, the two treaties are still separated within the consolidated document, ${ }^{130}$ and thus the policy statements in each treaty will be

http://europa.eu/abc/12lessons/lesson_6/index_en.htm (last visited Sept. 15, 2009) ("The aim was to stimulate industrial and commercial expansion within a large, unified economic area on a scale with the American market.").

124. European Commission, European strategy and co-operation in education and training, http://ec.europa.eu/education/lifelong-learning-policy/doc28_en.htm (last visited Sept. 15, 2009).

125. European Commission, Education \& Training - Our Mission, http://ec.europa.eu/education/ who-we-are/doc324_en.htm (last visited Sept 15, 2009).

126. See generally The CIA World Factbook, European Union, https://www.cia.gov/library/ publications/the-world-factbook/geos/ee.html (last visited Sept. 15, 2009)("The evolution of the European Union (EU) from a regional economic agreement among six neighboring states in 1951 to today's supranational organization of 27 countries across the European continent stands as an unprecedented phenomenon in the annals of history.").

127. See EUROPA website, The EU at a glance - Treaties and law, http://europa.eu/abc/ treaties/index_en.htm (last visited Sept 15, 2009).

128. Id.

129. Id.

130. See generally Consolidated Versions of the Treaty on European Union and of the Treaty Establishing the European Community, Dec. 29, 2006, 2006 O.J. (C 321), available at 
addressed separately in the discussion below.

First, the Treaty Establishing the European Community dictates the general policy directives of the European Union, and it clearly states that the main purpose of the European Union is to promote the "economic and social cohesion and solidarity among Member States."131 The European Union has the responsibility to achieve unification through several methods or means, including "contribution to education and training of quality and to the flowering of the cultures of the Member States."132 According to the Treaty, the European Union should "contribute to the development of quality education by encouraging cooperation between Member States."

However, this duty to contribute to the members' educational systems may only be fulfilled through certain means; specifically, the European Union may only make contributions "by supporting and supplementing [the Member States] action[s], while fully respecting the responsibility of the Member States for the content of teaching and the [organization] of education systems and their cultural and linguistic diversity." cannot overtly use legislation to dictate the educational systems of the Members States, the treaty states that the European Union should "adopt incentive measures" to increase systems which might lead to "[harmonization] of the laws and regulations of the Member States."135 For example, although the European Union cannot directly change a law that falls under a Member State's reserved power, the European Union could indirectly pressure a Member State's officials to accept certain types of policies or regulations in order to promote unified system of law across Europe. ${ }^{136}$

Unlike the general policy purposes in the Treaty Establishing the European Community, the Treaty on European Union addresses primarily economic objectives, such as the establishment of the Euro and the development of a unified European economic policy. ${ }^{137}$ Although this Treaty focuses on economics, the Treaty's beginning paragraphs state several economic objectives which directly relate to education policy because they emphasize the importance of eliminating national barriers to increase economic growth and development. ${ }^{138}$ The Treaty states that in order to "promote economic and social progress and a high level of employment," the European

http://eur-lex.europa.eu/LexUriServ/site/en/oj/2006/ce321/ce32120061229en00010331.pdf.

131. Consolidated Version of the Treaty Establishing the European Community, Dec. 29 2006, 2006 O.J. (C 321) E/37, at art. 2, available at http://eur-lex.europa.eu/LexUriServ/site/ en/oj/2006/ce321/ce32120061229en00010331.pdf [hereinafter Treaty Establishing the European Community].

132. Id. at art. $3(1)(q)$.

133. Id. at art. 149(1).

134. Id.

135. Id. at art. 149(4).

136. Unruh, supra note 48.

137. Consolidated Version of the Treaty on European Union, Dec. 29, 2006, 2006 O.J. (C 321) $\mathrm{E} / 5$, art. 2, available at http://eur-lex.europa.eu/LexUriServ/site/en/oj/2006/ce321/ ce32120061229en00010331.pdf [hereinafter Treaty on European Union].

138. Id. 
Union should develop policies towards this goal, "in particular through the creation of an area without internal frontiers [and] through the strengthening of economic and social cohesion . . .." ${ }^{139}$ Although primarily economic in purpose, the Treaty clearly resonates with policy objectives that are typically found in human rights agreements. For example, the Treaty states that the goal of the European Union is to "maintain and develop the Union as an area of freedom, security and justice, in which the free movement of persons is assured $\ldots . .140$

Through these two treaties, the European Convention on Human Rights may come to play a significant role because the combination of the Treaty of the European Community and the Treaty Establishing the European Union establishes a certain level of European citizenship that guarantees rights to social and economic protection. ${ }^{141}$ According to the Treaty on European Union, the European Union should "strengthen the protection of the rights and interests of the nationals of its Member States through the introduction of a citizenship of the Union." ${ }^{142}$ Because the European Union is designed primarily as an economic union, the treaties say little about fundamental human rights directly. ${ }^{143}$ However, the Treaty on European Union does state that because the European Union is "founded on the principles of liberty, democracy, respect for human rights and fundamental freedoms, and the rule of law, principles which are common to the Member States,"144 the European Union must respect the fundamental rights that are assured in the European Convention for the Protection of Human Rights. ${ }^{145}$ Thus, the interpretation of the European Court of Human Rights is important to the Member States because the European Union must respect the Convention on Human Rights, although the European Union itself is not a member of the Convention. ${ }^{146}$

139. Id.

140. Id.

141. See EUROPA website, The Amsterdam Treaty: the Union and the citizen, http://europa.eu/legislation_summaries/institutional_affairs/treaties/Amsterdam_treaty/a12000_e n.htm (last visited Sept. 3, 2009).

As set out in the Maastricht Treaty, any national of a Member State is a citizen of the Union. The aim of European citizenship is to strengthen and consolidate European identity by greater involvement of the citizens in the Community integration process. Thanks to the single market, citizens enjoy a series of general rights in various areas such as the free movement of goods and services, consumer protection and public health, equal opportunities and treatment, access

Id. to jobs and social protection.

142. Treaty on European Union, supra note 137, art. 2.

143. See European Union Website, Panorama of the EU, http://europa.eu/abc/panorama/ index en.htm (last visited Oct. 7, 2009).

144. Treaty on European Union, supra note 137, art. 6(1).

145. Id. at art. 6(2).

146. See Council of Europe, Simplified Chart of Signatures and Ratifications, http://conventions.coe.int/Treaty/Commun/ListeTableauCourt.asp?MA $=3 \& C M=16 \& C L=E N G$ (last visited Sept. 3, 2009). 
Although every one of the European Union's members has individually signed and ratified the Convention, the European Court of Justice, the supreme judicial court of the European Community, has held that the European Community could not accede to the Convention under the power given in the treaties. ${ }^{147}$ Indeed, the Court held that "[s]uch a modification of the system of protection of human rights would be of constitutional significance."

As a result of this decision, a lobbying effort was made in the European Community to include a human rights treaty in the proposed Treaty of Lisbon, a treaty which would form a European Constitution. ${ }^{149}$ This human rights portion of the proposed European Constitution, the European Union Charter of Fundamental Rights, ${ }^{150}$ provides the right to education and promises that the "right of parents to ensure the education and teaching of their children in conformity with their religious, philosophical and pedagogical convictions shall be respected." However, the Charter is not binding because the Constitution, although signed, has not been ratified and is not enforceable. ${ }^{152}$ However, the Charter is worth noting because any current European Union decision concerning policy could become the policy incorporated by any future European Constitution.

Further, the European Court of Human Rights should be brought into a discussion concerning education policy because any deference that the European Union gives to the Court's decisions could lead to a conflict with the stated policies of the European Union. As previously stated, the European Union was developed to encourage economic growth and development of its Member States. However, if the Court prevents the Member States from promoting educational choice, there will be restrictions on worker mobility that are unrelated to economic causes. Workers should be motivated by the laws of supply and demand and should be able to migrate where they are most needed. However, home-educating families which are restricted by the European Court of Human Rights from educating their children as desired would be limited in their opportunities to move within the European Union.

Although this situation might seem unlikely, it does come up as shown

147. Eurofound website, European Convention for the Protection of Human Rights and Fundamental Freedoms, http://www.eurofound.europa.eu/areas/industrialrelations/dictionary/ definitions/europeanconventionfortheprotectionofhumanrightsandfundamentalfreedoms.htm (last visited Sept. 3, 2009).

148. Id.

149. See EUROPA website, A Constitution for Europe, http://europa.eu/scadplus/constitution/ introduction_en.htm (last visited Sept. 3, 2009).

150. See generally Charter of Fundamental Rights of the European Union, Dec. 18, 2000, 2000 O.J. (364), available at http://www.europarl.europa.eu/charter/pdf/text_en.pdf.

151. Id. at art. 14.

152. See EUROPA website, Lisbon Treaty - Introduction, http://europa.eu/legislation summaries/institutional_affairs/treaties/Lisbon_treaty/indexs)_en.htm (last visited Oct. $\overline{7}$, 2009). For a general discussion of the human rights that incorporated by the Lisbon Treaty and the Charter of Fundamental Rights, see the EUROPA website, A Europe of Rights and Values, http://europa.eu/lisbon_treaty/glance/rights_values/index_en.htm (last visited Oct. 7, 2009). 
supra in Part III concerning home educating families who fled Germany for refuge in England. Some of these families attempted to seek better jobs in Germany, but they were driven away from those opportunities because of Germany's restriction on home education and the threats by the local authorities for not enrolling their children in state schools. ${ }^{153}$ One home educating family stated that the German draconian restriction on homeschooling "feels like persecution," 154 and another German family reported that their bank accounts were frozen and their car was seized merely because they where home educating their children. ${ }^{155}$

The European Union is supposed to grant "the right to travel, work, and live anywhere in the Union."156 However, if parents involved in home education are forced to decide between their children's education and seeking the best vocational opportunity, these guaranteed rights are extremely limited.

If the European Charter of Fundamental Rights is ratified and then interpreted to follow the decisions of the European Court of Human Rights which limit the choices in education, the economic opportunity of homeeducating parents in the European Union will be severely restricted. This conflict between the stated goals of the European Union and the Court's interpretation of the Charter of Fundamental Rights could create national barriers between the members, limit economic progress, and directly prevent the purposes of the European Union.

\section{B. Home Education and the European Union Policies on Education}

In order to encourage the development of its economic and political goals, the European Union produces general education policies that it suggests and promotes to the Member States. ${ }^{157}$ Given the added support of the Lisbon Treaty, the European Union has created a united educational strategy that consists of three overall objectives: "improving the quality and effectiveness of education and training systems; facilitating access to education and training systems; and opening up EU education and training systems to the wider world." 158

Home education should fit within the European Union's general policy and should be included in the future strategic decisions concerning European education. The following is a discussion of the policy concerns connected with home education, in addition to the concerns that were noted supra in Part III, and an explanation of how home education can be used as a method to fulfill

153. Francis-Pape \& Hall, supra note 47.

154. Id.

155. Id.

156. EUROPA Website, A Citizens' Europe, http://europa.eu/abc/12lessons/lesson_9/ index_en.htm (last visited Oct. 7, 2009).

157. See European Commission Website, European Strategy and Co-operation in Education and Training, supra note 124.

158. Id. 
the European Union's political and economic objectives.

In its strategies for European education in the twenty-first century, the European Union has set clear directives for its Members, and the European Union has said, "Schools need to set people on the path to a lifetime of learning, if they are to prepare them adequately for the modern world. A sound school education system ... also helps ensure open and democratic societies by training people in citizenship, solidarity and participative democracy."159 In an effort to comply with this statement, the "[e]ducation ministers from EU Member States have set themselves 13 specific areas for improvement in national systems, including the education and training of teachers, key competences, language learning, ICT, maths, science and technology, active citizenship and social cohesion."160

Independent public policy organizations have noted a significant decrease in the European Union of citizen engagement in "traditional democratic processes," and they have suggested that parents should be supported in developing young children "to recognize and develop their roles informing citizens. Parent, family, and women's education are particularly relevant."161 They also call for an "encouragement of initiatives that involve young people in the governance of their own educational and other institutions, as this is likely to be particularly helpful in creating a sense of engagement."162 Home education can serve as an effective means of academic education while promoting democratic values and active citizenship.

As noted supra in Part I, home education grew rapidly popular in the United States during the twentieth century. However, home education should not be a foreign concept to Europeans; prior to the introduction of governmentprovided and mass education in nineteenth century, home education was normal in Europe. ${ }^{163}$ As renewed European interest in home education has grown, its effectiveness has been closely followed, and the numbers clearly demonstrate that home education is a viable alternative to traditional schools. ${ }^{164}$ Alan Thomas and Harriet Pattison, fellow research associates at the Institute of Education, University of London, claim that home education is an "astonishingly efficient way to learn." 165 They claim that "[t]he ease, naturalness and immense intellectual potential of informal learning up to the

159. School Education: Equipping a New Generation, supra note 4.

160. Id.

161. PJB Associates, New Perspectives for Learning: Engaging People in ACtive CITIZENSHIP, BRIEFING PAPER 44 FOR THE EUROPEAN COMMISSION, 4 (June 2003), $\mathrm{http}: / / \mathrm{www} \cdot \mathrm{pjb} . c 0 . u \mathrm{k} / \mathrm{npl} / \mathrm{bp} 44 . \mathrm{htm}$.

162. Id. at 5 .

163. Cynthia M. Villalba, Creating Policy from Discursive Exchanges on Compulsory Education and Schooling in Sweden, 17 EVAL. \& RES. IN EDUC. 191, 193 (2003).

164. McIntyre-Bhatty, supra note 61 , at 247 ("International studies have consistently demonstrated the effectiveness of home education.").

165. Jessica Shepherd, No School like home: Jessica Shepherd meets the children who don't go to school, THE GUARDIAN, Aug. 19, 2008, at 1, available at http://www.guardian.co.uk/ education/2008/aug/19/schools.education. 
age of middle secondary school means they can learn certainly as much if not more." 166

However, some scholars and educators are concerned about the abilities of children educated at home to succeed beyond mere academics. As mentioned supra in Part II, the lack of daily peer interaction is a major source of unease for opponents of home education. They claim that a holistic approach to education requires social experiences as well as academics, and they fear that students educated at home will detrimentally lack the social exposure of the classroom and be deficient in peer interactions. For example, Daniel Monk expresses his concern that home educated students and their parents are stigmatized from the process, and he states that in the United Kingdom, "parents who choose to home educate are . . . perceived at best as somewhat eccentric or odd and at worst viewed with a degree of suspicion and unease." $" 167$

However, Karen McIntyre-Bhatty argues that there is little to no evidence that traditional schools promote social interaction any more than home education does. "Whereas school is seen to ensure the welfare of the child, home education is seen as a cause for concern with regard to welfare and development without evidence to support this assumption. ${ }^{168}$ According to her research, children in traditional schools "are no less at risk than those educated at home."169

Further, some scholars argue that restrictions on home education may cause harmful, unintended consequences. For example, Amanda Petrie notes that a ban or restriction on home education has extraordinary enforcement problems. She points out that a complete prohibition of home education is nearly impossible to enforce because enforcement methods are extremely limited. ${ }^{170}$ She argues that governments generally use three types of enforcement methods in this situation: (1) fines, (2) imprisonment of the parents, or (3) placement of the children in state custody. ${ }^{171}$ Petrie states that none of these lead to efficient enforcement because in the first method, the parents simply pay the fine and continue to home educate, while the second and third methods tear the families apart and do not keep the best interests of the children at issue. ${ }^{172}$ Thus, a ban on home education likely fails to promote educational policies that protect the best interests of the children.

Further, a ban on home education restricts the parents' personal liberty by limiting their right to choose their children's education. Larry Willmore argues that the interpretation of the right to education guaranteed in any international

166. Id.

167. Monk, supra note 94, at 589.

168. McIntyre-Bhatty, supra note 61 , at 255.

169. Id. at 256.

170. Petrie, supra note 17 , at 498.

171. Id. at 485,498 .

172. Id. at 498 . 
agreement should reflect the individuals' right to choose their own education. ${ }^{173}$ However, Daniel Monk points out that there is a tension between the negative right of the parents to avoid government intervention and the positive right of the child to receive an education. ${ }^{174}$ That is, a child's right to education is a positive right because it places a duty on the parents to provide an education. According to Monk, this tension leads to conflict "between the 'liberty' rights of parents to educate their children as they wish and the 'claim' rights made on behalf of children for the state to protect their right to education and to monitor how parents exercise their duty to provide education." 175 However, Monk argues that because the child's right to education is a positive right, the right to education should be construed as a welfare right. "Constructing education as a form of 'welfare,' emphasizing the extent to which it can be understood to be a 'service offered for the benefit of the recipients,' enables state involvement to be distinguished from totalitarian control.,"176

In contrast, Christian Beck, a professor of education at the Institute of Educational Research, University of Oslo, notes that allowing parents the flexibility to choose home education can promote individual liberty while encouraging social diversity. "When a centralized public school emphasizes universal national, secularized, and objective values, home educating environments may constitute post-modern, particular, local communities of shared values, which could be a threat to social integration, but could also be constructive and essential for maintaining social diversity and necessary to overall social integration." on individual, local and national levels depend . . . upon an atmosphere of open-mindedness and open communication." 178 Thus, it is possible that home education could actually increase social diversity while preserving the parents' individual right to choose their children's education.

Further, because modern types of state education require extraordinary centralization of bureaucracy and standardization, Beck argues such standardization loses more individual freedom than is desirable. "Home education has given impulses to arguments for personalized education and populistic perspectives in education ... home education has [the] effect on a more personalized education in school." ${ }^{179}$ Indeed, some authors note that the repressive laws against home education in Germany have been an attempt to suppress individual expression and produce a uniform society. ${ }^{180}$

173. See Willmore, supra note 119 , at 17.

174. Monk, supra note 94 , at 579.

175. Id.

176. Id.

177. Christian W. Beck, Home Education and Social Integration, 10 (unpublished article, available at http://folk.uio.no/cbeck/Home\%20education\%20and\%20social\%20integration.pdf).

178. Id. at 10 .

179. Christian W. Beck, Home Education: Globalization Otherwise? 4 MANAGING GLOBAL TRANSITIONS INT'L RES. J. 249, 258 (2006).

180. Monk, supra note 94 , at 583. 
Beck also notes that because state and home educators have their own forms of education, local authorities may perceive home education as conflicting with the interests of the state. However, simply because a home educator chooses a different method of education does not mean that "their interests or values conflict with those of society-at-large."181 Beck argues that "[i]t is neither home education's content nor methods that are perceived as threatening by public authorities, but the fact that home educators break with the public school system and conduct students' education in the home, outside of established schools." 182 Using Norway as an example, Beck notes that the most stigmatized European home educators are those who are forced underground and are unregistered. In contrast, those home educators who register and are recognized by the local government produce "well-socialized students."183

Similarly, Cynthia Villabla notes some local authorities misunderstand home educators because the terms that frame the home education debate are often confused. Villabla states that the "[p]ractical-pedagogical-cognitive versus political-social-moral elements are predominant in the discourse between the family and the education authorities in the municipality."184 The practicalpedagogical-cognitive elements focus on "school environment, age of the pupil, teaching methods and monitoring methods" while the second set of elements focuses on "more value-oriented items such as 'social training,' equity and equality ...."185 In discussions about home education, home educators tend to emphasize the practical-pedagogical cognitive elements while local authorities view home education with the second set of elements. However, Villabla notes that Swedish families that are home educating have formed unique, flexible solutions that allow both practical and social elements of education to be satisfied. $^{186}$

Indeed, because it is not the same thing as "taking the school to home," home education allows significantly more flexibility than traditional education. Although there are different styles of home education, home education is "a child-centred phenomena, whether it involves laissez-faire learning or formal teaching." 187 In a study of children educated at home in the United Kingdom, Paula Rothermel notes that the daily structure of home education differs significantly from that of a traditional school: "At home, children's learning was generally not 'planned' in the way it might be in school, particularly at this early age, and parents appeared not to think in terms of 'future progress' but

181. Id. at 4 .

182. Id. at 8-9.

183. Beck, supra note 177 , at 10 .

184. Villalba, supra note 163, at 204.

185. Id.

186. Id.

187. Paula Rothermel, Home Education: Comparison of Home-and School-educated children on PIPS Baseline Assessments, 2 J. OF EARLY CHILDHOOD RES. 273, 276 (2004). 
rather of allowing the children to learn at whatever pace suited them."188

Further, some studies have shown that home education may lead to more politically active and involved youth. For home educators in the United States, the family unit is the basic "building block of a national and international political network." Bruce Cooper and John Sureau of Fordham University's Graduate School of Education argue that "[a]lthough homeschool kids are taught individually or in small groups," they tend to be very political in their actions. ${ }^{189}$ That is, "they may also come to feel part of a vocal political, religious, and social grassroots community that knows and speaks its mind, reasserting a fundamental quality of grassroots democracy."190

In Paula Rothermel's study of home educated children in the United Kingdom, she discovered that they avoid much of the social-economic stratification present in most formal school situations. ${ }^{191}$ Further, contrary to the popular belief that only affluent children are successful in home education, Rothermel notes that home educated children from lower socio-economic backgrounds scored higher in test results than home educated children with affluent parents. ${ }^{192}$ According to Rothermel, children educated at home are "free from the stigma of being poor, simply because they are not learning in an environment where affluence and labelling are an issue."193 Although some home educating parents found living on one income a burden, Rothermel notes that the families preferred their freedom to home-educate over greater economic wealth. ${ }^{194}$

In a study of Canadian home-educators, researchers found that home education gives parents "the surest parental route for a specialized curriculum to match their child's particular needs." not been as extensive as that performed in North America, the current United Kingdom research shows similar results to North America, and British home educated children have outperformed children other types of traditional schools in the United Kingdom. ${ }^{196}$

In an attempt to develop a unified educational policy, the European Union encourages the concept of "Lifelong Learning." Lifelong Learning is a means for the European Union to "enhance economic competitiveness, while at the same time promoting social justice and democratic citizenship."197 This

188. Id. at 290.

189. Bruce S. Cooper \& John Sureau, The Politics of Homeschooling: New Developments, New Challenges, 21 EDUC. POL'Y 110, 128 (2007).

190. Id. at 128.

191. Rothermel, supra note 187, at 293.

192. Id.

193. Id.

194. Id. at 295-96.

195. Janice Aurini and Scott Davies, Choice Without Markets: Homeschooling in the Context of Private Education, 26 BRITISH J. OF Soc. OF EDUC. 461, 472 (2005).

196. Taylor \& Petrie, supra note 26 , at 68.

197. Veronica Crosbie, From Policy to Pedagogy: Widening the Discourse and Practice of the Learning Society in the European Union, 6 LANGUAGE AND INTERCULTURAL COMM. 234, 
system of learning emphasizes a lifetime of learning, and it encourages citizens to "learn how to learn, thus freeing them to engage in learning of their choosing in both formal and informal contexts."198 Within this policy, the "underpinning concerns of flexibility, transferability and mobility are the consistent driving concepts of the European Union."199 Originally, Lifelong Learning was developed as a way to accomplish an "education-centered society," and it is produced through national strategies which provide "opportunities for adults to learn what, when, and how they wished" and "maximize the learning opportunities and potential of the population as a whole." 200

In the European Union's public consultation "Schools for a $21^{\text {st }}$ Century" mentioned supra, the European Union asked how schools might be changed to "give young people with the competences and motivation to make learning a lifelong activity."201 In response, the public gave a "clear emphasis on the need to motivate young people to learn and to involve them in the learning process." 202 In their responses to the study, schools and national level organizations stated that teachers should have more autonomy in developing "the pedagogic strategies that work best for them.",203

Amanda Petrie notes that home education fits directly within the goals of Lifelong Learning, and she notes that parents who educated their children at home want a lifetime of learning "for their children from the day they are born, starting in the home and expanding into the community as the child grows," a form of education that she argues is "a truer definition of life-long learning."204

As a result, home education should play a role in the development of a Lifelong Learning policy of the European Union. Because there is little research on home education in Europe, there is admittedly some uncertainty concerning home education's survival in the European Union. However, if home education in Europe continues to exhibit the same success that it has had in North America, home education could be a viable educational alternative that would provide pedagogical flexibility, promote individual freedom, and accomplish the stated objectives of the European Union.

241 (2006).

198. Id. at 236 (emphasis in the original).

199. Jacky Brine, Lifelong Learning and the Knowledge Economy: Those That Know and Those That Do Not - the Discourse of the European Union, 32 BRITISH EDUC. RES. J. 649, 659 (2006).

200. Edwards \& Boreham, supra note 7, at 415 .

201. ANALYSIS OF PUBlic CONSULtATION, supra note 9, at pg. ii.

202. Id.

203. Commission of the European Communities, Commission Staff Working Document accompanying the Communication from the Commission to the Europeans Parliament, the Council, the European Economic and Social Committee and the Committee of the Regions, 4, Parl. Eur. Doc. SEC(2008)2177, available at http://ec.europa.eu/education/school21/sec2177 _en.pdf.

204. Petrie, supra note 17, at 483. 


\section{CONCLUSION}

The continent that has adopted a single currency is a long way from unity on home education. Although data remains scarce, support groups in several countries claim that they are receiving increasing numbers of requests from parents looking for alternatives to formal school systems, a movement being matched by legislative attempts to curtail its practice. ${ }^{205}$

As Europe quickly moves towards economic and political unification, education will become one of the most crucial areas of public policy in the age of globalization. It is particularly important for European policy makers to promote educational systems that will prepare Europe's future generations to compete effectively in the world market. However, the lack of European unification in educational policy is creating problems not only for education but also for worker mobility and economic development. The European Union's efforts to eliminate barriers between Member States are directly hindered by the conflicts in its Member's educational policies.

Most European home education regulations, including the United Kingdom's, are not written with proper communications involving the home education community, local authorities, and the legislature. ${ }^{206}$ Any discussions between policy makers and home education community must avoid mere speculation and must be based on research, and legislatures should develop any home education regulations with an eye on the evidence of home education's actual results.

Although home education may not be the proper method for every student, research shows that home education in North America and the United Kingdom rivals traditional schools in educational quality. Arguably, home education should not be encouraged on a grand scale because a mass-exit from state schools could prove detrimental to those left in government schools. ${ }^{207}$ However, home education should be at least an option from which European parents may choose, especially because education at home produces results directly congruent with the European Union's goals outlined in its plan for Improving Competences for the 21st Century: An Agenda for European Cooperation on Schools. ${ }^{208}$ As the Special Rapporteur on the right to education stated in his report, "[A] system of public, government-funded education should not entail the suppression of forms of education that do not

205. Guttman, supra note 54.

206. See generally McIntyre-Bhatty, supra note 61, at 241.

207. Chris Lubienski, supra note 103, at 169.

208. European Commission, Education \& Training, What Should Our Schools be Like in the 21 st Century?, http://ec.europa.eu/education/school-education/doc838_en.htm (last visited Mar. 9, 2009). 
require attendance at a school.,"209

As a result, the European Union should take a closer look at the possibility that home education could be an answer to its stated economic and political goals and to the development of a unified education policy. European policy makers should examine the conflict between the interpretation of the right to "education" or "schooling" in the European Convention on Human rights. Especially in light of the pending Charter of European Human Rights, the European Union should provide a unified position on the extent of the rights granted in the Convention. Although such a position would not be binding on the European Court of Human Rights, a unified policy in the European Union could prevent future conflicts between Member States and provide a policy guide for Member States when they prepare their own educational regulations. 